\title{
The Readiness of Leading and Teaching Staff to Develop Students' Sociocultural Competence in the Inclusive Learning Environment
}

\section{Galina Romanova}

State University for the Humanities and Technology, Department of Pedagogy, 22 Zelyonaya St., Orekhovo-Zuyevo, RU-142611 Moscow Region, Russia, galinaromanova3@rambler.ru

\begin{abstract}
The article aims to identify the level of readiness among the leading and teaching staff to develop students' sociocultural competence in the inclusive learning environment. The survey of 626 respondents, projective technique, essays, and expert evaluation of in-class and out-class activities revealed a low level of readiness among the leading and teaching staff. They have to improve their work to develop students' sociocultural competence after analysing the inclusive learning environment.
\end{abstract}

Keywords: vocational education, inclusive learning environment, sociocultural competence, students with disabilities, leading and teaching staff, readiness to develop sociocultural competence.

\section{Introduction}

The development of inclusive education at colleges and universities occupies one of the central places in the education policy across the globe. For the majority of young people with disabilities, equal educational opportunities (Council of the European Union \& European Commission, 2015) allow them to effectively meet their needs and increase their competitiveness in the labour market (Zorina, 2018). Vocational training of students with disabilities involves their engagement in the learning environment (Boginskaya, 2016), 
which contributes to their personal development and their own learning needs (Barton \& Slee, 1999; Romanova, 2017). Such engagement also encourages the implementation of intervention programmes (Nigmatullina, 2015), along with treating students with disabilities as full-fledged citizens (Shackelford, 2014).

In this regard, it is important to address the issue of developing an inclusive learning environment, which is a complex of conditions and influences that contribute to the development of personal characteristics of students with and without disabilities. The inclusive learning environment is related to the innovative development (European Agency for Special Needs and Inclusive Education, 2014) of the educational system which relies upon the cultural heritage and specific conditions for educating people with disabilities as a social group (Lebedeva, 2014). The system is based on a single system of quality career guidance which increases these people's social inclusion (Simonov \& Yevtushenko, 2016). The inclusive learning environment at colleges and universities ensures the adaptation of students with disabilities to the conditions of social diversity. It also enables professional and personal fulfilment, contributes to developing a lifestyle that supports autonomy and improves interpersonal communication. Therefore, students with disabilities and their peers gain learning and social experience in inclusive education.

In the inclusive learning environment, the focus is on enhancing the sociocultural interaction of students with and without disabilities during their joint education and training. The interaction, which enriches their sociocultural experience (Loreman, Forlin, \& Sharma, 2014; Mitchell, 2014), requires the strengthening of social and cultural components of the environment during vocational training. Students as subjects of the inclusive learning environment need to raise their cultural awareness of social conduct (Samokhvalova, 2012).

The social component describes the success of students' interpersonal communication and their full participation in public life, otherwise the failure generates a social issue (Beauchamp-Pryor, 2013). The cultural component takes into account the cultural differences of students with disabilities (Centre for Studies on Inclusive Education, 2018) regardless of their gender or religious beliefs (Booth \& Dyssegaard, 2015), as well as considers their preparation for living a full life in a multicultural society (European Agency for Special Needs and Inclusive Education, 2017). However, prevailing stereotypes regarding students with disabilities often present challenges to their full inclusion.

All subjects of the inclusive learning environment contribute to the effectiveness of the sociocultural interaction. These are the leading and teaching staff (department heads, lecturers, tutors, and resource specialists), students with and without disabilities, and their families (grandparents, parents, and siblings). The main types of disabilities refer to communicating, vision, hearing, movement, and multiple disabilities impairment.

During the sociocultural interaction, it is important to evaluate students' skills and abilities in situations relevant to their future jobs (Whiddett \& Hollyforde, 2003). In this regard, developing the sociocultural competence of different categories of students ensures 
success in interpersonal communication for a full participation in society. Sociocultural competence, as the author of the article suggests, is a student's integrative characteristics embodied as ability to initiate the intercultural communication in accordance with social and cultural components of the inclusive learning environment.

The structure of students' sociocultural competence, as the author of the article proposes, includes social readiness (knowledge, skills in social interaction); personal readiness (empathy, tolerance, social orientation, values, reflection, adaptability, stability, self-regulation); psychological readiness (knowledge, communication skills, perception and interaction in the inclusive learning environment).

Specifics of the sociocultural interaction in the inclusive learning environment determines the effective development of students' sociocultural competence. At that, there are advanced such integrative characteristics that increase students' integration into the inclusive learning environment. It is essential that there should be a learning community at colleges and universities, which is able to support students with disabilities and improve the joint education and training in an inclusive class. The learning community consists of subjects of the inclusive learning environment, who are able to solve problems of organising inclusive education.

The article aims to identify the level of readiness among the leading and teaching staff to develop students' sociocultural competence in the inclusive learning environment.

\section{Methodology}

The methodological framework for assessing the readiness of the leading and teaching staff to develop students' sociocultural competence is an inclusive approach to education. It justifies an increase in the degree of activity and equal participation of all categories of students in social life. This approach also determines ways to overcome discrimination against students with disabilities (Barnash, Plotnikova, \& Chaplygina, 2015) during their sociocultural interaction.

The framework underlies conditions for developing students' sociocultural competence. They include:

- motivating subjects of the inclusive learning environment to be engaged in individual and joint activities;

- successful personal fulfilment and self-development of each student;

- regarding inclusive education as a relevant mode of organising the inclusive learning environment at colleges and universities;

- developing inclusive values and inclusive thinking among subjects of the inclusive learning environment. 
These conditions are based on Bronfenbrenner's ecological systems theory (2009), which relates to socialisation and development of students with disabilities. According to the theory, the ecology of human development constitutes five systems:

- microsystem (a student's family);

- mesosystem (other students with and without disabilities, their families, the leading and teaching staff);

- exosystem (social service organisations);

- macrosystem (social inclusive values);

- chronosystem (development of all the systems while implementing the inclusive approach to education).

The research objectives are as follows:

- to reveal components of organising the inclusive learning environment;

- to determine aspects of the overall readiness among subjects of the inclusive learning environment to develop students' sociocultural competence on the basis of the revealed components;

- to identify the level of their overall the readiness in accordance with the determined aspects;

- to list parameters of assessing readiness of the leading and teaching staff to develop students' sociocultural competence in the inclusive learning environment;

- to identify the level of their readiness in accordance with the parameters.

This study involved 626 respondents - subjects of the inclusive learning environment at colleges and universities in the Moscow Region (Russia). There were 262 representatives of the leading and teaching staff, 290 students (including 65 students with disabilities), and 74 families of students (including 22 families of students with disabilities). The sampling validity was proved by Paniotto's method (Paniotto \& Maksimenko, 2003) (with the sampling error of 4\%), using Excel 2010 spreadsheets. The minimum sample size was determined to ensure the representativeness of the research findings. The acceptable statistical significance is $90 \%$, with the standard deviation of 1.65 .

The components of organising the inclusive learning environment, which contributes to the development of students' sociocultural competence at colleges and universities, are presented in Table 1.

The components of organising the inclusive learning environment were assessed. A survey, projective technique, essays, and expert evaluation of in-class and out-class activities were the assessment tools. They allowed determining the respondents' overall readiness to develop students' sociocultural competence. The aspects of the overall readiness include knowledge about disabilities and its types, positive motivation to implement inclusive education, willingness to work together, and interaction skills. 
Table 1

Structure of the Inclusive Learning Environment for Developing Students' Sociocultural Competence

\begin{tabular}{ll}
$\begin{array}{l}\text { Components of organising the in- } \\
\text { clusive learning environment }\end{array}$ & $\begin{array}{c}\text { Parameters of organising the inclusive learning envi- } \\
\text { ronment }\end{array}$ \\
\hline Man-made environment & $\begin{array}{l}\text { architecture and space arrangement, printed and electronic } \\
\text { information resources (in accordance with the require- } \\
\text { ments for organising inclusive education). }\end{array}$ \\
\hline Social environment & $\begin{array}{l}\text { interaction among subjects of the inclusive learning } \\
\text { environment; } \\
\text { specifics of interaction among subjects of the inclusive } \\
\text { learning environment; } \\
\text { the readiness of the leading and teaching staff for orga- } \\
\text { nising inclusive education; } \\
\text { students' readiness and interest in interpersonal commu- } \\
\text { nication and personal growth; } \\
\text { families' readiness and interest in inclusive education. } \\
\text { counselling for developing the inclusive learning envi- } \\
\text { ronment; } \\
\text { content, technologies, methods of educational activity and } \\
\text { interaction determined by the specifics of the environment; } \\
\text { psychological attitude and favourable creative atmosphere, } \\
\text { possibilities of personal fulfilment of subjects of the inclu- } \\
\text { sive learning environment; } \\
\text { interaction among the leading and teaching staff, students, } \\
\text { their families, representatives of state and public organisa- } \\
\text { tions, associations, and employers; } \\
\text { corporate interests, common objectives of subjects of the } \\
\text { inclusive learning environment. }\end{array}$ \\
\hline Physical activity environment & \\
&
\end{tabular}

The questions in the author's survey were the following:

- How should students with disabilities study: in an inclusive class, in a learning disability class, or remotely?

- Which class will you choose: heterogeneous (mixed, inclusive), homogeneous, or not sure?

- What are the main problems in inclusive education: a lack of knowledge, communication problems, psychological unreadiness?

All the respondents answered questions 1, 3, while only students and their families answered question 2 . They all filled in forms anonymously and marked one variant for questions 1, 2, and they could select several answers to question 3. Each answer was analysed as a percentage for all the respondents. 
The projective technique Dembo-Rubinstein (Rubinstein, 2004) was employed for self-assessing the joint activities of students and their families in the inclusive learning environment, as well as interaction skills. The respondents marked a dot on a vertical line relevant to their current state under these scales. The value of the self-assessment as percentage was determined as a distance from the bottom to the marked dot.

The respondents submitted hand-written essays (under 200 words) "Pros and cons of inclusion", which revealed the main problems of organising inclusive education. These problems were grouped to observe which ones were addressed more often (as percentage).

Expert evaluation of in-class and out-class activities also enabled to list such problems. The evaluation was based on analysing students' sociocultural interaction in the classroom, during planning periods, meetings with students' families. The leading and teaching staff participated in the sessions.

The overall readiness as a result of assessing the components of the inclusive learning environment allowed identifying the level of the leading and teaching staff to develop students' sociocultural competence. The parameters for assessing the level included:

- knowledge of special psychology and special needs education;

- knowledge of students' psychological and physiological characteristics in accordance with the type of disability;

- knowledge of technologies for interaction with students with disabilities;

- implementation of these technologies;

- knowledge of technologies for interaction with families of students with disabilities;

- implementation of these technologies;

- emotional acceptance of students with disabilities;

- ability to include students with disabilities in joint activities;

- knowledge of designing technologies for students' individual learning routes;

- ability to develop them (Romanova, 2020).

The parameters allowed determining a low, medium, or high level in accordance with the type of disability: communicating, vision, hearing, movement, and multiple disabilities impairment. The results were based on surveying the leading and teaching staff, instructors' manuals for planning periods and conducting them, frequency of meetings of the leading and teaching staff with families of students with disabilities.

\section{Results}

There are results of how the level of the overall readiness among all the subjects of the inclusive learning environment to develop students' sociocultural competence was identified stage by stage. The leading and teaching staff, students with and without disabilities, and their families were among the subjects. 
In the survey, the answers to the question "How should students with disabilities study: in an inclusive class, in a learning disability class, or remotely?" (Figure 1) prove that $75 \%$ students with disabilities and $40 \%$ of their families advocate for the development of the inclusive learning environment. The leading and teaching staff (35\%), students without disabilities (40\%), and their families (40\%) noted that students with disabilities should study in learning disabilities classes. No category of respondents was inclined to select the remote inclusive education settings.

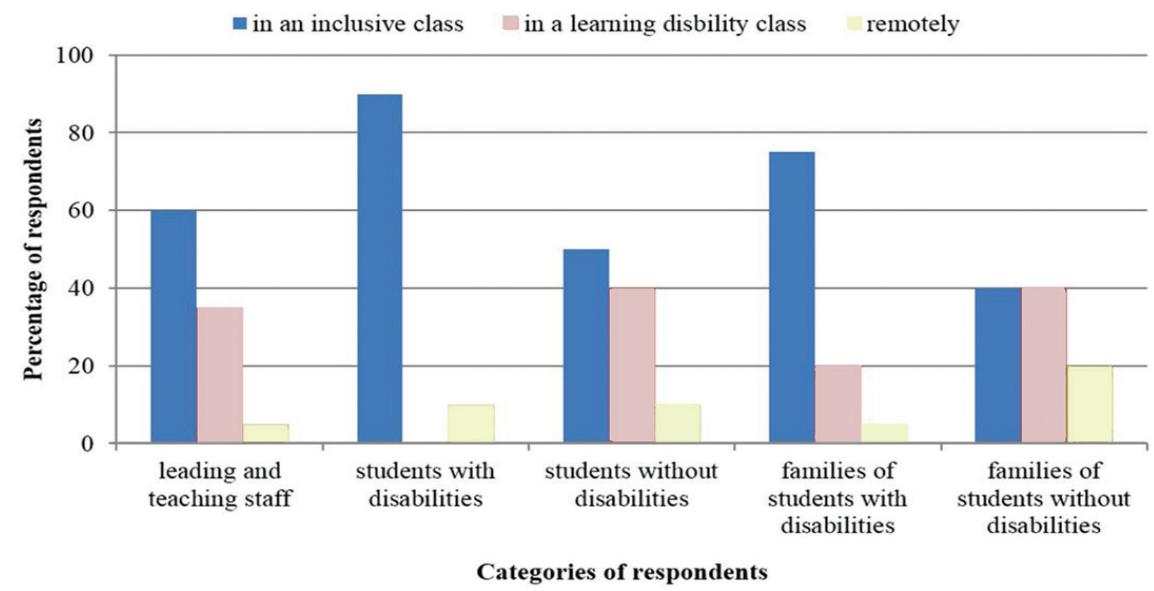

Figure 1. Distribution of the respondents' answers to the question "How should students with disabilities study?"

The answers to the question "Which class will you choose: heterogeneous (mixed, inclusive), homogeneous, or not sure?" (Figure 2) also indicate that students with disabilities $(60 \%)$ and their families (52\%) are more motivated to develop the inclusive learning environment. The students without disabilities (65\%) and their families (62\%) support a homogeneous class. 


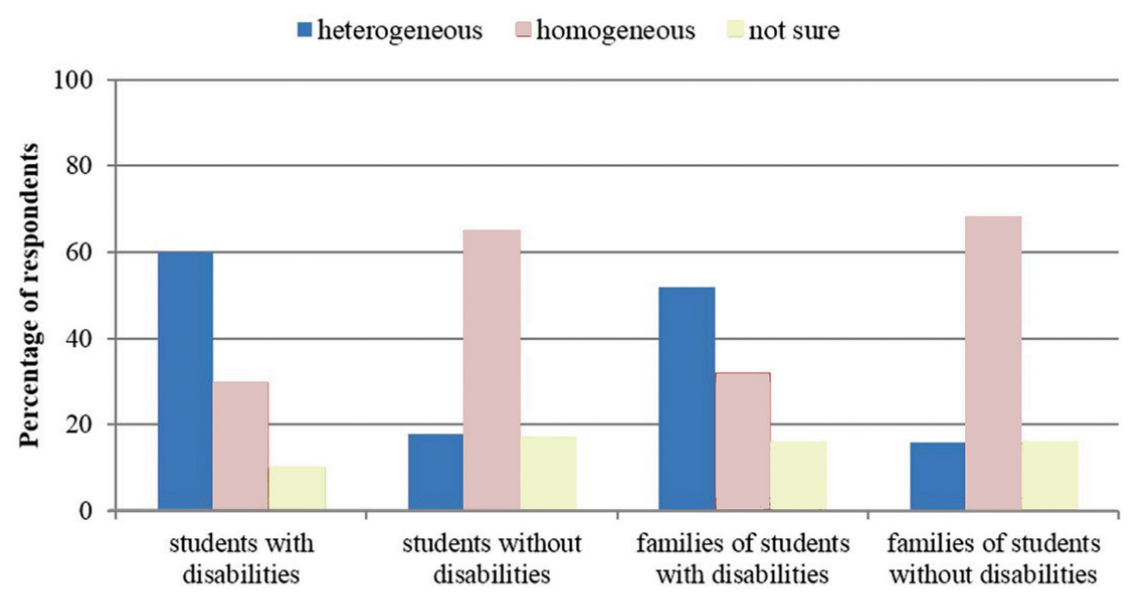

\section{Categories of respondents}

Figure 2. Distribution of the respondents' answers to the question "Which class will you choose?"

The results of using the projective technique (Figure 3) demonstrate the respondents' willingness to work together rather than their interaction skills in the inclusive learning environment. In particular, $95 \%$ students with disabilities and $75 \%$ of their families are willing to, which contrasts with $20 \%$ students without disabilities and $40 \%$ of their families.

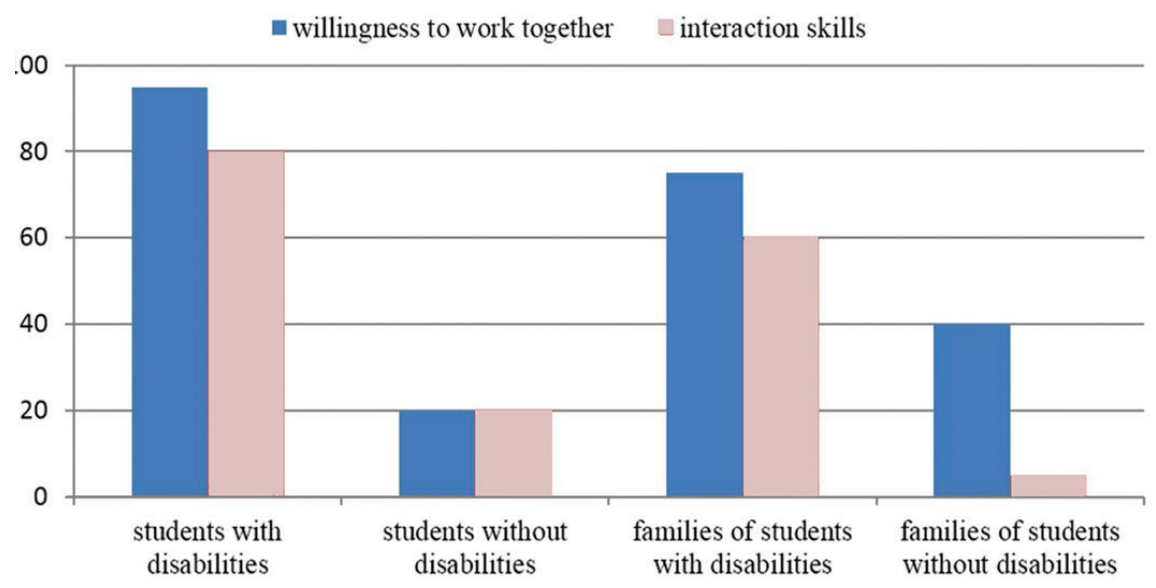

Categories of respondents

Figure 3. Distribution of the respondents' answers according to the scales "Willingness to work together" and "Interaction skills" 
The answers to the question "What are the main problems in inclusive education: a lack of knowledge, communication problems, psychological unreadiness?" (Figure 4) show that students with disabilities and their families are more willing to study in the inclusive learning environment than the other categories of respondents. The main problem is communication problems revealed by $25 \%$ students with disabilities and $65 \%$ of their families, $72 \%$ the leading and teaching staff, and $65 \%$ of students without disabilities. All the families of students without disabilities (100\%) selected a lack of knowledge as the main problem, while $10 \%$ families of students with disabilities decided it was the least important problem.

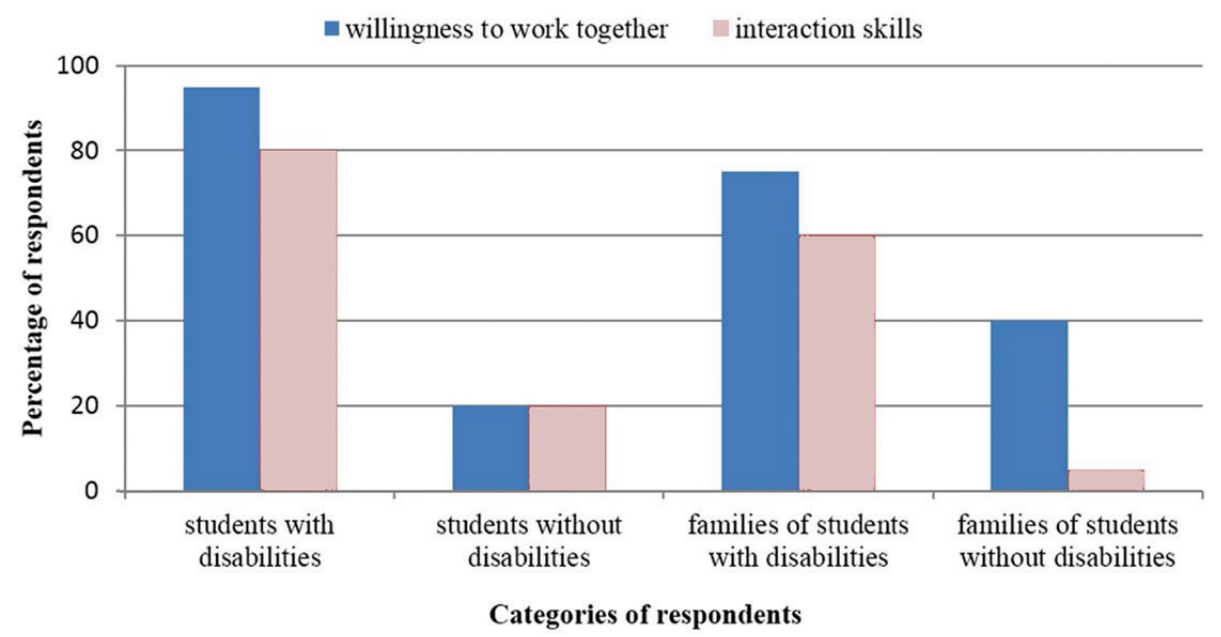

Figure 4. Distribution of the respondents' answers to the question "What are the main problems in inclusive education?"

Essays and expert evaluation of in-class and out-class activities allowed the respondents to describe the main problems of organising inclusive education. The leading and teaching staff noted several problems. They did not know effective ways of communicating with students with disabilities (72\%), they lacked knowledge about types of disabilities (65\%), they were unaware of ways to organise joint activities between students with and without disabilities (63\%), and they experienced psychological discomfort (26\%).

Students with disabilities identified several problems. The leading and teaching staff were unwilling to provide a high level of instruction in inclusive classes (63\%), there was a lack of opportunities for personal fulfilment during out-class activities (57\%), they exhibited compassion (43\%), and they experienced psychological discomfort (13\%).

Students without disabilities named other problems. They were unaware of ways to organise joint activities with students with disabilities (65\%), they lacked knowledge about types of disabilities (45\%), and they experienced psychological discomfort (39\%). Next, 
the leading and teaching staff were unwilling to provide a high level of instruction in inclusive classes (35\%). They were also concerned about reduced learning outcomes due to the increased attention that the leading and teaching staff had to pay to students with disabilities (27\%). They felt that students with disabilities received higher grades (12\%).

There are total results (as a percentage) of assessing the overall readiness among all the respondents to develop students' sociocultural competence (Table 2).

Table 2

Assessing the Overall Readiness of Subjects of the Inclusive Learning Environment to Develop Students' Sociocultural Competence

\begin{tabular}{lcccc}
\hline $\begin{array}{c}\text { Subjects of the } \\
\text { inclusive learning } \\
\text { environment }\end{array}$ & $\begin{array}{c}\text { Knowledge about } \\
\text { types of } \\
\text { disabilities }\end{array}$ & $\begin{array}{c}\text { Positive motivation } \\
\text { to implement } \\
\text { inclusive education }\end{array}$ & $\begin{array}{c}\text { Willingness } \\
\text { to work } \\
\text { together }\end{array}$ & $\begin{array}{c}\text { Interaction } \\
\text { skills }\end{array}$ \\
\hline $\begin{array}{l}\text { Leading and teach- } \\
\text { ing staff }\end{array}$ & $30-40 \%$ & $60 \%$ & $50-60 \%$ & $30 \%$ \\
\hline $\begin{array}{l}\text { Students with disa- } \\
\text { bilities }\end{array}$ & $100 \%$ & $90 \%$ & $95 \%$ & $80 \%$ \\
\hline $\begin{array}{l}\text { Students without } \\
\text { disabilities }\end{array}$ & $40-50 \%$ & $50 \%$ & $20 \%$ & $20 \%$ \\
\hline $\begin{array}{l}\text { Families of students } \\
\text { with disabilities }\end{array}$ & $100 \%$ & $75 \%$ & $75 \%$ & $60 \%$ \\
\hline $\begin{array}{l}\text { Families of students } \\
\text { without disabilities }\end{array}$ & $10 \%$ & $40 \%$ & $40 \%$ & $5 \%$ \\
\hline
\end{tabular}

A high level of the overall readiness is characteristic of students with disabilities (91.25\% on average) and their families (77.5\%), whereas a low level is typical of students without disabilities (33.75\%) and their families (23.75\%). The average level of the overall readiness is among the leading and teaching staff, who are knowledgeable enough about types of disabilities and skilled enough at interacting. As regards the other aspects of the overall readiness, a low level of knowledge about types of disabilities and interaction skills is found among families of students without disabilities ( $10 \%$ and $5 \%$ respectively). So is their motivation to implement inclusive education (40\%). Students without disabilities are the least willing to work together (20\%).

The survey of the leading and teaching staff helped determine the level of their readiness to develop students' sociocultural competence in the inclusive learning environment. Table 3 displays the results as a series of percentages (low, medium, high) separated by a slash. 
Table 3

Assessing the Level of Readiness among the Leading and Teaching Staff to Develop

Students'Sociocultural Competence in the Inclusive Learning Environment

\begin{tabular}{|c|c|c|c|c|c|}
\hline $\begin{array}{l}\text { Parameters for } \\
\text { assessing the readiness } \\
\text { of leading and teaching staff }\end{array}$ & 蒫 & 晜 & 是 & ¿ & 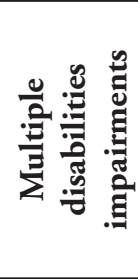 \\
\hline $\begin{array}{l}\text { Knowledge of special psychology } \\
\text { and special needs education }\end{array}$ & $31 / 56 / 13$ & $39 / 57 / 4$ & $35 / 61 / 4$ & $26 / 70 / 4$ & $31 / 65 / 4$ \\
\hline $\begin{array}{l}\text { Knowledge of students' psycholo- } \\
\text { gical and physiological characteris- } \\
\text { tics in accordance with the type of } \\
\text { disability }\end{array}$ & $31 / 56 / 13$ & $44 / 52 / 4$ & $31 / 65 / 4$ & $39 / 57 / 4$ & $26 / 70 / 4$ \\
\hline $\begin{array}{l}\text { Knowledge of technologies for inter- } \\
\text { action with students with disabilities }\end{array}$ & $31 / 52 / 17$ & $43 / 48 / 9$ & $49 / 43 / 8$ & $26 / 61 / 13$ & $31 / 60 / 9$ \\
\hline $\begin{array}{l}\text { Implementation of these techno- } \\
\text { logies }\end{array}$ & $30 / 61 / 9$ & $43 / 34 / 23$ & $52 / 35 / 13$ & $39 / 57 / 4$ & $35 / 65 / 0$ \\
\hline $\begin{array}{l}\text { Knowledge of technologies for inter- } \\
\text { action with families of students with } \\
\text { disabilities }\end{array}$ & $17 / 61 / 22$ & $30 / 61 / 9$ & $22 / 70 / 8$ & $70 / 30 / 0$ & $31 / 56 / 13$ \\
\hline $\begin{array}{l}\text { Implementation of these techno- } \\
\text { logies }\end{array}$ & $30 / 57 / 13$ & $35 / 56 / 9$ & $35 / 57 / 8$ & $22 / 74 / 4$ & $26 / 70 / 4$ \\
\hline $\begin{array}{l}\text { Emotional acceptance of students } \\
\text { with disabilities }\end{array}$ & $17 / 52 / 30$ & $26 / 39 / 35$ & $17 / 57 / 26$ & $13 / 65 / 22$ & $22 / 74 / 4$ \\
\hline $\begin{array}{l}\text { Ability to include students with } \\
\text { disabilities in joint activities }\end{array}$ & $31 / 56 / 13$ & $39 / 52 / 9$ & $35 / 57 / 8$ & $35 / 57 / 8$ & $30 / 57 / 13$ \\
\hline $\begin{array}{l}\text { Knowledge of designing technolo- } \\
\text { gies for students' individual learning } \\
\text { routes }\end{array}$ & $43 / 52 / 5$ & $52 / 35 / 13$ & $48 / 40 / 12$ & $48 / 48 / 4$ & $39 / 52 / 9$ \\
\hline Ability to develop them & $52 / 35 / 13$ & $57 / 26 / 17$ & $58 / 30 / 12$ & $52 / 39 / 9$ & $52 / 35 / 13$ \\
\hline
\end{tabular}

The survey results demonstrate that the leading and teaching staff are more ready to emotionally accept students (a high level ranges from $4 \%$ to 35\%). Nevertheless, they are the least knowledgeable about special psychology and special needs education (4\%-13\%), as well as about psychological and physiological characteristics in accordance with the type of disability (4\%-13\%). The main problems relate to a low level of developing students' individual learning routes (52\%-58\%), as well as the lacking knowledge of designing technologies for such routes $(39 \%-52 \%)$ and knowledge of technologies for interaction with students with disabilities (30\%-52\%). 
The expert evaluation of instructors' manuals for planning periods and meetings with students' families reveal the irregular work to develop students' sociocultural competence. In addition, students' families are not actively engaged in the life of the academic group, including various forms of joint activities. Interaction with students' families is mainly associated with individual consultations. There are practically no joint activities for families of students with and without disabilities.

\section{Discussion}

The assessed level of readiness to develop students' sociocultural competence in the inclusive learning environment was monitored at the corresponding vertical and horizontal levels of the environment. The vertical level determines the parameters for assessing the readiness in an ascending order as personality - personality, personality - group, personality - team (individual student, a student's family, academic group, faculty, college or university). The horizontal level revealed specifics of developing students' sociocultural competence during in-class and out-class activities.

These are students with disabilities and their families who assess the overall readiness to develop the sociocultural competence higher than the leading and teaching staff, students without disabilities and their families. So development of students with disabilities is high enough in the microsystem described in Bronfenbrenner's ecological systems theory (2009). Respectively, there is a low level of readiness among the leading and teaching staff to develop students' sociocultural competence.

The findings disclosed the main problem inherent to subjects of the inclusive learning environment. They include low motivation to work together, the use of inefficient educational technologies, excessive facilitation of the life of the subjects, a lack of opportunities for personal fulfilment of students with disabilities during out-class activities, a focus only on the needs of students with disabilities and their families.

To eliminate the problems, it is necessary to increasingly motivate subjects of the inclusive learning environment to work together (Reinders, 2011). It is also important to provide targeted aid, without addressing only the needs of students with disabilities and their families. Moreover, the leading and teaching staff should utilise effective technologies of developing students' sociocultural competence in the inclusive learning environment. At that, it is possible to invite several teachers to instruct (Pancsofar \& Petroff, 2016), and involve family members in inclusive education (Kiyama \& Harper, 2018). Using resource centres to assist in teaching students with disabilities (Kovács, 2019) and providing counselling services in inclusive education (Morgado, Cortés-Vega, López-Gavira, Álvarez, \& Moriña, 2016) will be advantageous.

It is advisable that the leading and teaching staff should increase their work aimed at developing students' sociocultural competence in accordance with all the parameters of 
assessing the readiness. With this in mind, it is recommended to regularly hold workshops and meetings for the leading and teaching staff, teaching councils to generalise experience in solving problems related to development of students' sociocultural competence, with families of students, representatives of public organisations, and employers involved. Such measures will encourage the leading and teaching staff to more effectively organise the inclusive learning environment (Woodcock \& Woolfson, 2019) in accordance with the inclusive policy at college or university (Kendall, 2016).

It is reasonable to combine individual and group consultations of resource teachers and special education teachers with students, their families, the leading and teaching staff after assessment. The focus should be on the developing students with disabilities in the mesosystem and exosystem, as proposed in the ecological systems theory by Bronfenbrenner (2009), since colleges and universities are able to increase the level of their overall readiness. In this regard, it is critical to develop the inclusive culture not only during in-class and out-class activities, but also interactions of the leading and teaching staff with students (Sakız \& Sarıcalı, 2018; Walden, Trytten, \& Shehab, 2018).

All things considered, it is necessary to monitor the overall readiness among subjects of the inclusive learning environment to develop students' sociocultural competence. Additionally, it is required to monitor the readiness of the leading and teaching staff to develop it. The monitoring should be based on analysing the components of the inclusive learning environment: man-made, social, and physical activity. There should be assessment, which will allow analysing the utilised educational technologies, in-class assignments, as well as personal characteristics of the leading and teaching staff, and their emotional support of students with disabilities (Lipka, Forkosh Baruch, \& Meer, 2019).

\section{Conclusions}

Identifying the level of readiness among the leading and teaching staff to develop students' sociocultural competence in the inclusive learning environment contributes to the problem of organising inclusive education at colleges and universities. The inclusive approach to education and ecological systems theory are the theoretical framework, which allows increasing activity and equal participation of different categories of students in the sociocultural interaction. All subjects of the inclusive learning environment contribute to improving the interaction: the leading and teaching staff, students with and without disabilities, and their families.

During the research, components of organising the inclusive learning environment were revealed: man-made, social, and physical activity. There were determined aspects of the overall readiness among subjects of the inclusive learning environment to develop students' sociocultural competence on the basis of the revealed components. The aspects 
include the knowledge about types of disabilities, positive motivation to implement inclusive education, willingness to work together, and interaction skills.

The findings demonstrate a high level of the overall readiness among students with disabilities and their families to develop the sociocultural competence, whereas a low level is characteristic of students without disabilities and their families. There is a low level of readiness among the leading and teaching staff to develop students' sociocultural competence in the inclusive learning environment. The assessment was based on the parameters aimed to increase the work to develop the competence. It is required to monitor the readiness among all subjects of the inclusive learning environment.

In the course of monitoring, it is necessary to describe in detail quantitative indicators of changes that should be subject to qualitative analysis and mathematical processing. On the one hand, this is a limitation of the study; on the other hand, this is a field for further research related to development of students' sociocultural competence. It is also reasonable to analyse the level of the readiness under study in accordance with the structure of students' sociocultural competence, which comprises the social, personal, and psychological readiness. At that, relevant assessment tools should be employed.

\section{Acknowledgement}

The research was conducted on the basis of the following programmes: "Vocational education without borders - equal opportunities for disabled people" (01-12.2018), "Implementation of inclusive vocational education of disabled people in the Moscow region" (12.2016-12.2020), "Model of an inclusive educational environment to promote the development of students' sociocultural competence".

\section{References}

Barnash, A. V., Plotnikova, O. A., \& Chaplygina, M. L. (2015). Inkljuzivnyj podhod k obrazovaniju [An inclusive approach to education]. Electronic Scientific and Methodological Journal "Concept", 13, 2041-2045.

Barton, L., \& Slee, R. (1999). Competition, selection and inclusive education: Some observations. International Journal of Inclusive Education, 3(1), 3-12. https://doi.org/10.1080/136031199285147 Beauchamp-Pryor, K. (2013). Disabled students in Welsh higher education. Rotterdam: Sense Publishers. https://doi.org/10.1007/978-94-6209-344-7

Boginskaya, Y. V. (2016). Sovremennoe sostojanie vysshego obrazovanija studentov s invalidnost'ju $\mathrm{v}$ vuzah Evropy I SShA [The current state of higher education of students with disabilities in the European and US universities]. Internet Magazine "World of Science", 4(4). Retrieved from: http://mir-nauki.com/PDF/35PDMN416.pdf 
Booth, T., \& Dyssegaard, B. (2015). Quality is not enough: The contribution of inclusive values to the development of education for all. Canterbury: Enabling Education Network. Retrieved from: https://www.eenet.org.uk/resources/docs/QualityIsNotEnough.pdf

Bronfenbrenner, U. (2009). The ecology of human development: Experiments by nature and design. Cambridge, MA: Harvard University Press.

Centre for Studies on Inclusive Education. (2018). Index for inclusion: Developing learning and participation in schools. Bristol: Centre for Studies on Inclusive Education.

Council of the European Union, \& European Commission. (2015). Joint report of the council and the commission on the implementation of the strategic framework for European cooperation in education and training (ET 2020) - New priorities for European cooperation in education and training. Official Journal of the European Union, 417, 25-35. Retrieved from: https://eurlex.europa.eu/legal-content/EN/TXT/?uri=celex:52015XG1215\%2802\%29

European Agency for Special Needs and Inclusive Education. (2014). Inclusive education in Europe: Putting theory into practice. Retrieved from: https://www.europeanagency.org/sites/default/ files/IC\%20Researchers\%20paper.pdf

European Agency for Special Needs and Inclusive Education. (2017). Inclusive education for learners with disabilities. Brussels: European Parliament. Retrieved from: https://www. european-agency.org/sites/default/files/Events/EPSeminar/Seminar_report_Inclusive_ Education.pdf

Kendall, L. (2016). Higher education and disability: Exploring student experiences. Cogent Education, 3(1), 1-12. https://doi.org/10.1080/2331186X.2016.1256142

Kiyama, J. M., \& Harper, C. E. (2018). Beyond hovering: A conceptual argument for an inclusive model of family engagement in higher education. The Review of Higher Education, 41(3), 365-385. https://doi.org/10.1353/rhe.2018.0012

Kovács, K. (2019). Empowerment of students with disabilities in university setting. In S. Halder \& V. Argyropoulos (Eds.), Inclusion, Equity and Access for Individuals with Disabilities (pp. 581-601). https://doi.org/10.1007/978-981-13-5962-0_28

Lebedeva, S. S. (2014). Nepreryvnoe obrazovanie invalidov kak social'noj gruppy [Continuing education of people with disabilities as a social group]. Continuing Education: XXI Century, 1(5), 1-14. Retrieved from: https://cyberleninka.ru/article/n/nepreryvnoe-obrazovanieinvalidov-kak-sotsialnoy-gruppy/viewer

Lipka, O., Forkosh Baruch, A., \& Meer, Y. (2019). Academic support model for post-secondary school students with learning disabilities: Student and instructor perceptions. International Journal of Inclusive Education, 23(2), 142-157. https://doi.org/10.1080/13603116.2018.1427151

Loreman, T., Forlin, C., \& Sharma, U. (2014). Measuring indicators of inclusive education: A systematic review of the literature. In C. Forlin \& T. Loreman (Eds.), International Perspectives on Inclusive Education (Vol. 3, pp. 165-187). UK: Emerald Group Publishing Limited. https:// doi.org/10.1108/S1479-363620140000003024

Mitchell, D. (2014). What really works in special and inclusive education: Using evidence-based teaching strategies (2nd ed.). New York: Routledge. https://doi.org/10.4324/9780203105313 
Morgado, B., Cortés-Vega, M. D., López-Gavira, R., Álvarez, E., \& Moriña, A. (2016). Inclusive education in higher education? Journal of Research in Special Educational Needs, 16(1), 639-642. https://doi.org/10.1111/1471-3802.12323

Nigmatullina, I. A. (2015). Inkljuzivnaja psihologija - Innovacionnoe napravlenie podgotovki magistrov (budushhih special'nyh psihologov) [Inclusive psychology - An innovative direction in postgraduate training (future special psychologists)]. In M. V. Ovchinnikov (Ed.), Proceedings of the all-Russian scientific and practical conference "Inclusive Vocational Education" (pp. 17-21). Chelyabinsk: Chelyabinsk State University.

Pancsofar, N., \& Petroff, J. G. (2016). Teachers' experiences with co-teaching as a model for inclusive education. International Journal of Inclusive Education, 20(10), 1043-1053. https:// doi.org/10.1080/13603116.2016.1145264

Paniotto, V. I., \& Maksimenko, V. S. (2003). Kolichestvennye metody v sociologicheskih issledovanijah [Quantitative methods in sociological research]. Retrieved from: https://sociology. knu.ua/sites/default/files/library/elopen/pm2003.pdf

Reinders, H. S. (2011). The power of inclusion and friendship. Journal of Religion, Disability \& Health, 15(4), 431-436. Kiev. https://doi.org/10.1080/15228967.2011.619341

Romanova, G. A. (2017). Modelirovanie inkljuzivnojo brazovatel'noj sredy vuza i ee problemy [Modeling of the inclusive educational environment of the university and its problems]. Inclusion in Education, 2(2), 48-57.

Romanova, G. A. (2020). Inclusive educational environment in students' social-cultural competence development. Proceedings of the First International Volga Region Conference on Economics, Humanities and Sports (FICEHS 2019), 564-569. Presented at the Proceedings of the First International Volga Region Conference on Economics, Humanities and Sports (FICEHS 2019). Kazan: Atlantis Press. https://doi.org/10.2991/aebmr.k.200114.131

Rubinstein, S. Ya. (2004). Eksperimental'nye metodiki patopsihologii i opyt ih primeneniya: Prakticheskoe rukovodstvo [Experimental techniques of pathopsychology and their implementation]. Moscow: Moscow State Psychological and Pedagogical University.

Sakız, H., \& Sarıcalı, M. (2018). Including students with visual difficulty within higher education: Necessary steps. Exceptionality, 26(4), 266-282. https://doi.org/10.1080/09362835.2017.1283627

Samokhvalova, I. G. (2012). Sociokul'turnaja kompetentnost' lichnosti [Sociocultural competence of a person]. Pedagogical Education in Russia, 2, 71-74. Retrieved from: https://cyberleninka. $\mathrm{ru} /$ article/n/sotsiokulturnaya-kompetentnost-lichnosti/viewer

Shackelford, E. L. (2014). Beyond disability etiquette matters: Step outside your comfort zone useful tools to educate yourself! Bloomington, Indiana: Xlibris.

Simonov, A. P., \& Yevtushenko, I. V. (2016). Model' professional'noj orientacii obuchajushhihsja s OVZ so slozhnym defektom v uslovijah Severo-Vostoka Rossii (na primere Magadanskoj oblasti) [Model of vocational guidance for students with disabilities with a complex defect in the North-East of Russia (on the basis of the Magadan region]. Modern High Technology, 5(3), 595-599. Retrieved from: https://www.top-technologies.ru/ru/article/view?id=35960 
Walden, S. E., Trytten, D. A., \& Shehab, R. L. (2018). Research-based recommendations for creating an inclusive culture for diversity and equity in engineering education. 2018 IEEE Global Engineering Education Conference (EDUCON), 1591-1597. Tenerife: IEEE. https://doi. org/10.1109/EDUCON.2018.8363425

Whiddett, S., \& Hollyforde, S. (2003). A practical guide to competencies: How to enhance individual and organisational performance. London: Chartered Institute of Personnel and Development. Woodcock, S., \& Woolfson, L. M. (2019). Are leaders leading the way with inclusion? Teachers' perceptions of systemic support and barriers towards inclusion. International Journal of Educational Research, 93, 232-242 https://doi.org/10.1016/j.ijer.2018.11.004

Zorina, E. E. (2018). Preodolenie bar'erov pri realizacii inkljuzivnogo obrazovanija v vuze [Eradicating the barriers to inclusive higher education]. The Education and Science Journal, 20(5), 165-184. https://doi.org/10.17853/1994-5639-2018-5-165-184

\section{Vadovaujančiojo ir mokymo personalo pasirengimas inkliuzinejje mokymosi aplinkoje ugdyti studentu sociokultūrinę kompetenciją}

\section{Galina Romanova}

Valstybinis humanitarinių mokslų ir technologijos universitetas, Pedagogikos katedra, Zelionaja gatvė 22, RU-142611, Orechovo Zujevas, Maskvos sritis, Rusija, galinaromanova3@rambler.ru

\section{Santrauka}

Inkliuzinis ugdymas užtikrina studentų su negalia (bendravimo, regejiimo, klausos, judejjimo ir mišri negalia) adaptaciją socialinėmis ir kultūrinèmis sąlygomis. Šiame straipsnyje siekiama nustatyti vadovaujančiojo ir mokymo personalo pasirengimo lygị ugdyti studentų sociokultūrinę kompetenciją inkliuzinejje mokymosi aplinkoje. Lygio vertinimas remiasi integraciniu požiūriu i švietimą ir Bronfenbrenerio ekologine vystymosi teorija. Inkliuzinės mokymosi aplinkos organizavimo komponentai (žmogaus sukurta, socialinė ir fizinė veikla) leido nustatyti bendro pasirengimo aspektus (žinias apie negalią ir jos rūšis, teigiamą motyvaciją îgyvendinti inkliuzinị ugdymą, norą dirbti kartu ir bendravimo igūdžius). Šiame tyrime dalyvavo 626 respondentai, iš jų 262 vadovaujančiojo ir mokymo personalo atstovai, 290 studentų (iš jų 65 studentai su negalia) ir 74 studentų šeimos (ịskaitant 22 studentų su negalia šeimas). Maskvos srities kolegijose ir universitetuose respondentų bendras pasirengimo lygis buvo aukštas - 91,25 proc. studentų su negalia ir 77,5 proc. jų šeimų, vidutinis - 45 proc. vadovaujančiojo ir mokymo personalo, žemas - 33,75 proc. studentų be negalios ir 23,75 proc. jų šeimų. Siekiant efektyvios integracijos patartina reguliariai rengti seminarus ir susitikimus vadovaujančiajam ir mokymo personalui. 
Tai padètų apibendrinti patirtị sprendžiant problemas, susijusias su studentų sociokultūrinès kompetencijos ugdymu, studentų šeimomis, visuomeninių organizacijų atstovais ir darbdaviais. Socialinès ir kultūrinès kompetencijos ugdymas padidina studentų aktyvumą ir vienodą dalyvavimą sociokultūrinèje veikloje, todèl būtina stebėti visų inkliuzinès mokymosi aplinkos dalyvių pasirengimą.

Esminiai žodžiai: profesinis mokymas, inkliuzine mokymosi aplinka, sociokultūrinè kompetencija, studentai su negalia, vadovaujantysis ir mokymo personalas, pasirengimas pletoti sociokultūrinę kompetencija. 